\title{
The Roots of Law in Malay Muslim Society
}

\author{
Muhammadrorfee-E Musor \\ Dept. of Social Sciences, Faculty of Humanities and Social Sciences, Prince of Songkla \\ University, Pattani Campus \\ A.Muang CH.Pattani 94180 Thailand \\ Email: rofee.2521@gmail.com
}

Accepted: March 17, 2013 Published: April 24, 2013

Doi:10.5296/jsr.v4i1.3413 URL: http://dx.doi.org/10.5296/jsr.v4i1.3413

\begin{abstract}
This article will explore the roots of law in Malay Muslim Society. In the incident research is a documentary research which objectives of the study are to explore the historical background of the areas which will illustrate the reasons that were responsible for shaping the current Malay society and discuss about the relationship between the local norm and concept of norm which is a central to sociology of law. The study found that three major periods that influence the Malay society. The first was before entering of Hindu into this area, the local people following the custom of tribe; second was the arrival of Hinduism that influenced people's lives, the Hindu law has been implemented into society at this time and ; third was the entering of Islam into the Malay Peninsula, the Islamic law has been implemented and changed the local people's beliefs. Malay society is governed by 'adat', (a word borrowed from Arabic) and Muslim law in addition to the general law is applicable to all communities. 'Adat' as norm in Malay society, being the living law at a certain time in a certain place, adat is elastic and adaptable to social needs and as such not suitable for codification. 'Adat' is commonly classified into two varieties; the adat perpateh and the adat temengung. The primary purpose of adat is threefold the protection, regulation and preservation of the society.
\end{abstract}

Keywords: Malay Muslim Society, Adat, Malay Adat, Islamic law, norm, sociology of law

\section{Introduction}

As we know in different social contexts, the appearances of norms in society are also differently manifested. The aim of this article is to analyze norms within Malay Muslim context in Malaysia. However, the historical background and understanding of that area is also important when discussing about norms in a Malay Muslim context which will illustrate the reason behind that. Hence, this article going to start with an overview of the Malay Muslim society, interpret the roots of law in Malay Muslim society and finally discuss the norm in that society, especially from a sociology of law perspective. 


\section{Malay Muslim communities: An overview}

In order to understand the Malay Muslim communities, it is very important to note the historical background of the Malay Peninsula and the Malays themselves. Malaysia is a geographical federation divided into two distinct regions separated by about 650 kilometers of the South China sea. The Malay Peninsula comprises what used to be called Malaya and extends from the Thai border in the north to the straits of Johor in the south. Sabah and Sarawak previously referred to as west Malaysia are located on the island of Borneo. Malaysia is a plural society with three main groups, namely, Malays, Chinese and Indians. Three major periods were largely responsible for shaping the current Malaysian society. The first was the founding of the Malacca Sultanate at the beginning of fifteenth century; second was the spread of Islam to South-east Asia and its subsequent entrenchment in the indigenous culture; and finally was British colonial rules which brought with it constitutional government and the common law system (Wu Min Aun, 1990).

\section{Hindu influencing in the Malay world}

Azman bin Abu Hassan (2010) considered the historical background of the Malay Peninsula of Malaya throughout the seventh century B.C., the country and its inhabitants had gone through various stages of cultural influences which had led to the development of a set of rules that govern the country until the beginning of the colonial era. The Malay Peninsula was favoured by the Indian and Chinese traders plying the sea routes between India and China. At the beginning of this era, the first Indian settlement had already established itself in Malaya until the fourteenth century Indian culture puts its stamp on the Malays' way of life, introducing Indian religion, laws and language in this region. Even replacing the native tribal organization with government by a Sultan. The Indianisation was the result of a two way traffic, first from the Indian traders and secondly it was possibility of the spreading of ideas of Hinduism that the idea of Hinduism spread more from the visits by the Malays to the centre of Hindu culture in India. During the first to the thirteenth century, a number of Hinduised empires arises in South East Asia for example, Funan in the 1st century, Sri Vijaya in the 7th century and Majapahit in the 13th century. In the Malay Peninsula, the Hindu influence can be found in the early civilized states such as Kedah at that time called Langkasuka and in Pahang. The cultural influence spread into Malaya and affected the political and social institution.

The concept of state and kinship was changed, tribal policies were raised in status to kingdoms, the concept of god-king had been introduced in order to replace the tribal chieftan. Holding power by virtue of a manifest divinity that transcended the customary law of the tribe, the god-king was liberated from the traditional constrain that had limited the power of the tribal chieftan. The influence of Hindu law and the custom can also be found in the Court hierarchy, prerogatives and ceremonies in the marriage customary rites and in the Malay customary law. The tribal and matriarchal elements in Malay customary law were in some areas modified so as to make the customary law monarchial and patriarchal. The Hindu Law which finds its sources 
in the Dharmasutra (law books in prose), Dharmasastra (law book in verses) and Hindu customary law contains an extensive legal system. It covers family law, succession, property, contract, crime and punishment, judicial procedure and evidence. Of all branches of Hindu law, constitutional law and criminal law have left most traces in Medieval Malay States. The Sultan is the sovereign and exercise the function of the executive, judicial and sometime legislature. His power is absolute and this influence to some extent still exist in the modern Malay community today whereby the monarchial institutions and some aspects of feudal values are part of the Malays way of life and is very sacred.

\section{Islamic influence in the Malay world}

During the 14th country Malacca rose to be the centre of Malay civilization in the Peninsula. Due to its geographical strategic position it had become a famous port and a trade centre linking Middle-East and China. By the end of 15th century Malacca had become a power of great importance in South East Asia. During the time of Megat Iskandar Shah the first ruler of Malacca some Arabic Moors, Persian as well as Bengalis moved to trade in Malacca. These merchants were very rich with large business and fortune, brought with them mollahs and priests learned in Islamic teachings. Sultan Iskandar Shah derived great profit and satisfaction by the prosperity of trade in Malacca. He was very pleased and in return he did them honor, giving them places to live and places to built their mosque. The Islamic missionaries in Malacca then tried very hard to convert the Sultan to Muslim and at last Sultan Iskandar Shah with all his house turned Muslim. The rapid spreading of Islamic teachings in Malacca and the whole Peninsula was indirectly improved by the Hindu influence in the Malay society. The Ruler under the Hindu influence was portrayed as a god-king and he demands absolute loyalty of his subjects. When Sultan Iskandar converted to Islam he made all his people do the same without any opposition. Within half a century, Malacca became a centre of Islamic studies. It converted the whole Peninsula by force of arms and made their Rulers accept the new faith and dispatched missionaries along every trade route. The early missionaries of Islam found out that officials were administering a system of Hindu customary law and the Malays were very much influenced by mysticism and they tried very hard to change that in compliance with the Islamic teachings using every method of propaganda at their command. This was made easier because they had the blessing from the Sultan of the respective states and the concept of blind loyalty to the feudal lords in the Malay community. When they converted the Sultan to Islam, his subjects would do the same. At this time Islam indeed was welcomed because not only did it free the Malays from the oppressive stratification of Hinduism and absolute power of the Hindu ruler but also change the ideological aspect of the community. Instead of being a subject of a god-king, their perspective of the world has widened. This opened a new era of development to a community that has been living in the state of backwardness and oppression of the feudal lords. (Azman bin Abu Hassan, 2010)

Hence, the origin of this Malay royalty was due to the marriage of Indian immigrants with the daughters of local chiefs, their children inheriting Hindu ideas of territory and divinity grafted onto primitive Malay conceptions of tribe and of the magical power of chiefs and medicine 
men (R.H.Hickling, 2001).

\section{'Adat' as norm in Malay society}

Malays in Malaysia are governed by adat and Muslim law in addition to the general law applicable to all communities.

'Adat', a word borrowed from Arabic in general means a right to conduct and in common usage it stands for a variety of things all connected with proper social behavior and culture. Thus it will connote rules of etiquette and the ceremonies prescribed for a particular occasion such as marriage as well as those customs which have legal consequences. 'Adat' derives its patriarchal character from the Hindu influence. Being the living law at a certain time in a certain place, adat is elastic and adaptable to social needs and as such not suitable for codification. The decision of tribal chiefs and local institutions will give a more faithful picture of living adat law. Although adat law is very adaptable, this does not mean, however that the chiefs can hand out decisions at will. A great number of adat regulation put a limit to their freedom. As being defined by its common usage 'adat' will connote a code of behavior and social etiquette governing the Malay society. It is a social norm established by long usage laid down by a paramount political power or rules of human conduct which is recognized as being obligatory. A study on adat will not only reflect its legal consequences but also the way of life and the identity of the Malays themselves (Azman bin Abu Hassan, 2010).

Wu Min Aun (1990) considered 'Adat' not homogeneous; it varies in each region. Except in Sarawak, adat is largely unwritten. In its original form, it is an oral tradition varying with time. Some of the old written codes do exist but what was actually practiced might not have been accurately recorded in the written rules. In fact, it has been contended that the written codes do not accurately reflect all the customary traditions. Some confusion does exist with regard to the judicial criteria for proof of custom. Under English law, there must be evidence that accustom is, among other things, ancient, uninterrupted, uniform, constant, reasonable, certain and acquiesced in. These criteria are not necessarily appropriate to provide adat because of its fluidity and variety. Adat may be judicially proved on the basis of local evidence. 'Adat' is commonly classified into two varieties; the adat perpateh and the adat temengung. Adat temengung merely refers to a variety of adat based on the patriarchal system. While, Adat perpateh, is a distinct tradition practiced among the Malays in present day Negeri Sembilan and Nanning in Malacca, areas settled by Minangkabau immigrants from Sumatra. Adat perpateh is practiced in such matters as land tenure, inheritance, lineage and the election of the traditional chiefs.

The distinction between Adat perpateh and Adat temengung in the content as Azman bin Abu Hassan (2010) illustrates in his article that Adat perpateh has provided a democratic constitutional structure to some extent in order to safeguard justice compared to adat temengung. Adat perpateh finds expression in traditional verses and sayings of the matriarchal tribes in Negeri Sembilan. The sayings were handed down from generation to 
generation and are known to everyone and the ignorance of law cannot be an honest and valid excuse. The sayings are simple and can be easily memorized. In these communities the family is responsible for its members, penalties like imprisonment and mutilation would only mean an extra burden to them and so adat perpateh aims at restitution and compensation of the injured rather than punishment of and revenge on the culprit. Even when a victim dies adat perpateh seek to restore the loss of a breadwinner by compelling the killer's tribe to substitute one of its members or pay blood money instead. Adat pepateh was an extremely mild system of laws, lenient to the first offender and always ready to condone a wrong if due restitution was made. Moreover, Adat pepateh tries to balance between leniency and undue tolerance of crime.

While, Adat temengung changed its character under Hindu influence, adat temengung found its way to the peninsula via the sultanate of Palembang and Malacca. The adat temengung was administered on autocratic lines. It was not the common concern of the people. It is a command of the sovereign backed by sanction. In the absence of precise rules, common sense came to be regarded as the only possible law, discussion as the only possible procedure. The interest of the Malay chiefs lay in the director of exacting heavy fines, slavery and vindicating his authority by the cruel punishment of any man who dared to gainsay him or disregard his command.

The significance of 'adat' in the Malay society we can see from the Malay proverb, biar mati anak, jangan mati adat, better the child dies, rather than the custom. This reflects the fact that the Malay people are more willing to lose the most beloved child than willing to violate traditional practices. The reversal is significant, reflecting as it does a popular shift in values, not only in relation to the position of the individual in society, but in relation to the authority of custom itself. The maxims of Malay life are more important than the maxims of equity in English law. Kecil di kandung ibu, besar dikandung adat, mati dikandung tanah, when young we are embraced by our mother, when adult by custom, when dead by the earth, such is the traditional view of the villager's life. However, the proverb of modern version is said to be, biar mati adat, jangan mati anak; let the custom die, rather than the child, reflects that increasing recognition of the importance of the individual which finds expression in Part II of the Federal Constitution, where the fundamental liberties of citizens and others are set down. Just as oral proverbs embody the adat, so now does writing embody much of the law; and as society develops, adat withers, to be replaced by other fashions of thought, other pressures on behavior ( R.H.Hickling, 2001).

The value of adat lies, then, in its early vitality as living law. It belongs to, is part of the society in and for which it has been created, and that society remains alive and active, changing as necessary with the need of that society. Custom grows out of, and is shaped by, the habits of society, it necessarily reflects the way of life of the community within which it operates. Where a custom expresses a particular belief, and the reason for holding that belief has gone, then the custom will disappear. In this fashion R.H. Hickling (2001) stated that the pressures of education, the influence of radio, television and the printed word, and the 
development of a kind of world culture based on a common diet of television series and newspaper features, videotapes, VCD, DVD and other fast foods, are bringing about a revolution in which local and national customs and boundaries are ceasing to retain their old significance.

\section{'Adat' in Malay society VS norm in sociology of law}

Hydén, H., \& Svensson, M. (2008), considered the concept of norms as crucial when trying to understand the relationships between law and society and that the concept of norm is as central to sociology of law as for example the concept of attitudes is central to social psychology. In addition, sociology of law embraces the notion of essence and accident, and explains them in the process of understanding the concept of norm. The essences of norm are: (a) behavioral instructions (imperative); (b) socially reproduction; (c) the individual's understanding of surrounding expectations regarding their own behavior. The imperative has to be socially reproduced in such a way that it represents the individuals' understanding of surrounding expectations regarding their own behavior. The accidental of norm are: sanctions; the original of norm; the context or arena; system-oriented or value-oriented; the internal function of the norm; the purpose of the norm; etc.

Azman bin Abu Hassan (2010) defined a social norm is a customary mode of behavior - it is what people in a given society are expected by their fellow members to do, not only because such behavior is usual but also because it is deemed good. The man who uphold the nouns will be rewarded by his fellow men with approbation, honors and the like. These are positive sanctions. The man who does not uphold the norms will be punished by negative sanction. They may take many difference forms, ranging from minor social sanction, such as ridicule and refusal to interact with him, to the most extreme - that of ostracism by the community. Economic sanction such as refusal to cooperate in economic activity and political sanction such as the deprivation of an elected person of one's support and vote may be applied. Legal sanctions are those in which force may be used by a recognized authority.

However, concerning sanctions, Hydén, H., \& Svensson, M. (2008), argue that sanctions are not conditions for the norm concept. Sanctions may be built into the norm, as in system-oriented norms. This category of norms is a consequence of the rationale the system is built upon. Hydén, H., \& Svensson, M. give an example of technical norms in relation to building of houses or cars or whatever. If we as a constructor do not follow the instructions stemming from the strength of materials or other laws of nature, we are deemed to fail in our mission. The sanction does not have to be articulated, it is more or less an automatic consequence of deviations from the norm. The same can be said about economic behavior according to the rationale of the market or another economic system. If we do not invest in accordance with the imperatives of the market, we are expected to fail and lose money, contrary to the rationale of the economic system. Even rules and norms which are about definitions have no explicit sanction, but they are imperatives, which are socially reproduced and expressions of the expectations from the surrounding environment. The sanction can here 
be said to be indirect. If we do not accept the imperative in terms of a definition, we are without possibilities for communication and action within that sector of society where this definition belongs.

Therefore, if we used the notions of essence and accident of norm which are described by Hydén, H., \& Svensson, M. (2008), we can see in the process of understanding the concept of norm in Malay Muslim communities as below:

\section{Essence of norm}

(1) Imperative; behavioral instructions that is how to act in order to live in Malay communities. As mentioned above adat as a living law in Malay community, the Malay people willing to follow adat in order to be accepted by community member. Malay community can be classified into two groups. One following adat temenggong and the other adat pepateh. Adat pepateh was adhered to by the Malays inhibiting Negeri Sembilan and certain parts in Malacca, especially Naning. Malays in other parts of the Peninsula are supposed to follow adat temenggong. Though both the adat originated from tribal organization in the past, it is in adat pepateh that is the remnants of tribal structure are clearly evident.

(2) Socially reproduction; how local people reproduce adat in the local community. Adat was never committed to writing, it was constantly overridden by autocratic chiefs and unjust judges, varied in each state, they did not harmonized with the doctrine of Islam that it professed to follow, it was often expressed in metaphors or proverbs that seemed to baffled interpretation. These unwritten laws especially the sententious saying that has been handed down by oral tradition however has the full force of public opinion behind them, reference to them is sufficient to compel even an unjust judge to do justice to the litigants before him. In other words, these tribal saying derived their legal characteristic because it is the expression of an instinctive sense of right and the common consciousness of the people (Azman bin Abu Hassan, 2010).

(3) the individual's understanding of surrounding expectations; regarding their own behavior. The Malay in general is not a litigious person. When he happens to be a litigant, he appears to be unhappy about it. This traditional character even exists until now. When conflict arises the injured is made whole by applying the customary remedy which in most cases, especially in adat pepateh society consist in awarding compensation. Arbitration pays a very important role. Petty disputes were referred to arbitration by the village elders. Only when failed or when the dispute was serious enough to require stronger measures were the services of the lembaga sought. The judges were usually the village elders or the chiefs of the clans who uphold the norms of their society. As they are not bound by precedent though a precedent may have a great persuasive authority, they can reinterpret the adat in such a way to suit the present day conditions. One must note that the interpretation has not been developed into an esateric science so there will be no serious objection to reinterpretation which is intended to keep pace with the time. Moreover, Adat itself aimed at harmony; indeed, a proverb asserts, truly 
enough, that adat sentosa di dalam negeri, with adat there is peace in the land. The primary purpose of adat is threefold, the protection, regulation and preservation of the society (R.H.Hickling, 2001).

\section{The accidental of norm}

(1) the original of norm; the origin of Malay adat was due to the marriage of Indian immigrants (Hindu) with the daughters of local chiefs (tribe), and Islamic law. The system of Islamic law has its foundation in religious belief, Islamic law takes its inspiration from the Qur'an (Koran), it is the foundation of Islamic law; divided into 114 chapter or surahs (a word of uncertain origin, but used in the Qur'an itself, and meaning probably. It offers guidance on all matters of right and wrong. The corpus of Islamic law is known generally as the Shariah (the way): and basic consequences of such law being in principle divine revelation is that it cannot be altered. It extends to all areas of human being, from the moment of wakefulness to the moment of sleep. The four roots of Islamic law that founder of the Shafi'I school ${ }^{1}$ as

a) The Qur'an

b) The sunnah, traditions of the Prophet;

c) Ijtihad, a personal effort to decide an issue on the basis of the first two roots, a) and b), or qiyas, reasoning by analogy (a common habit of lawyers); and

d) Ijma, consensus, now perhaps the most far-reaching of the four roots, insofar as law is concerned.

However, in order to compromise between Malay adat and Islamic Law Malaysia government established 'The Council of Religion and Malay Custom' that's can issue a fatwa, or ruling on any point of Muslim law doctrine or Malay customary law. What is significant in this procedure is that in all cases the Council must have due regard to the Adat Istiadat Melayu or Malay customary law. The strict tenets of Islam are thus made capable of modification, to accord with Malay adat. Nevertheless, at the village level the legal norm that was applied consisted of Islamic law and customary law of adat. The administered Islamic law was not pure Islamic law but modified by Malay customary practices (Wu Min Aun,

${ }^{1}$ The four classical schools of Islamic jurisprudence (of Mahdab) are each named by students of the classical jurist who taught them. The schools and where they are commonly found are

- Hanafi (Turkey, Pakistan, the Balkans, Central Asia, Indian subcontinent, Afghanistan, China and Egypt)

- Maliki (North Africa, the Muslim areas of West Africa, and several of the Arab states of the Persian Gulf)

- Shafii (Arabia, Indonesia, Malaysia, Maldives, Egypt, Somalia, Eritrea, Ethiopia, Yemen and southern parts of India)

- Hanbali (Arabia).

These four schools share most of their rulings, but differ on the particular hadiths they accept as authentic and the weight they give to analogy or reason (qiyas) in deciding difficulties. 
1990). According to the fatwa which issued by The Council of Religion and Malay Custom covers many aspects in daily life including faith, cooperate/economics, medical care, social, food \& drink etc. The example of a fatwa as below;

- shake hands with the opposite sex, Fatwa Committee of the National Council for Islamic Religious Affairs Kali Ke-79 that met on the 6th to 8th September 2007 and had discussion concerning shaking hands with the opposite sex. Feedback has been decided that in principle of Islamic law shaking hands with the opposite sex is forbidden. However, in some cases difficult to avoid, it is possible, but in a controlled situation that is not the culture in the Muslim community.

- eating a Bird's Nest, Fatwa Committee of the National Council for Islamic Religious Affairs Kali Ke-79 that met on the 6th to 8th September 2007 and had discussion concerning eating Bird's nest. Feedback has been decided that the law of eating bird's nest is to be allowed.

(2) the context or arena; the Malay adat was not only implemented in Malay Muslim in Malaysia but Malay adat also influenced to Malay Muslim in another area such as Indonesia, Brunei and the southern provinces part of Thailand until todays but exists in different forms in different areas.

(3) system-oriented or value-oriented; The value of Malay adat in its early vitality as living law. It belongs to, is part of the society in and for which it has been created, and like that society remains alive and active, changing as necessary with the need of that society. Moreover, in east Malaysia, both Sarawak and Sabah there have five criteria for the judicial recognition of adat in Sarawak that are tests for the validity of a custom in that state, are
a. Reasonableness;
b. Generality;
c. Antiquity;
d. Consistency with morality; and
e. Not contrary to public policy.

These tests are probably valid for the recognition of adat in Malaysia generally; but the observer should bear in mind that adat is limited in its area and, often, in its application; its reasonableness has to be tested against the behavior of those within whose area it operates and its antiquity depends on the memories of the elders of the community. It is a powerful force within society, because of its very nature, of the gulf that exists between it and written word. (John Wayne Chamberlain Sirau, 1984)

\section{Conclusion}

In the Malay Muslim society the three stages of societal development can be seen; firstly, before the entering of Hindu, the local people following the custom of tribe. Secondly, the 
arrival of Hinduism that influenced people's lives, the Hindu law has been implemented into society at this time, and thirdly, the entering of Islam in Peninsular Malaya. The Islamic law has been implemented and changed the local people's beliefs. Hence, the evolution of Malay custom depended on the degree of recognition accorded by the ruler or other authority in whose name the law was administered. Malay customary law is a mixture of Malay customs and Islamic law, the principles of Islamic law only being adopted to the extent that such principles were consistent with Malay customary law. Adat aimed at harmony; indeed, a proverb asserts, truly enough, that adat sentosa di dalam negeri, with adat there is peace in the land. The primary purpose of adat is threefold, the protection, regulation and preservation of society (R.H.Hickling, 2001)

Although Malaysia has been used the concept of democratic and legal system from the West after British colonization but they integrated the new systems from British tradition and the custom of local people to this country. The obvious example is the administration of justice, under traditional Malay system, the hierarchy corresponded to the judiciary at the lowest level and it was the headman who was the leader of his community. He has a constable know in Malay as a mata-mata to assist him. He was largely responsible for maintaining law and order in his community. More serious offences were sent for trial by the District Chief but he had no power to order judicial execution which was the privilege of the ruler. And at the village level the law that was applied consisted of Islamic law and customary law of adat. The Islamic law administered was not pure Islamic law but modified by Malay customary practices. There were no organized courts. The British installed a legal system based on their legal concepts and integrated the religious courts into the general framework of court administration. This interference in the administration of Muslim law was done through State Councils which became the legislative bodies of the states (Wu Min Aun, 1990)

\section{References}

Anwarul Yagin. 1997. Law and Society in Malaysia. Kuala Lumpur: International law book Services.

Azman bin Abu Hassan. 2010. The Sources of Law and Legal System of the Malays. [Online]Available:http://www.agc.gov.my/agc/index.php?option=com_idoblog\&task= viewpost\&id=819\&Itemid=0\&lang=e (March 3, 2010).

Francesca M. Cancian. 1975. What are norms? A Study of Beliefs and Action in a Maya Community. Cambridge University Press.

Hydén, H., \& Svensson, M. ,2008. The concept of norms in sociology of law. In H. Hydén \& P. Wickenberg (Eds.), Contributions n sociology of law (Vol. 29). Lund: Lund studies in Sociology of Law.

Hydén, H., \& Wickenberg, P. (Eds.). (2008). Contributions in Sociology of Law, remarks from a Swedish horizon. Lund: Lund Studies in Sociology of Law.

Hydén, Håkan (1999) "Even a stepchild eventually grows up: On the identity of Sociology of law". Retfaerd 85, 1999, no 2.

R.H.Hickling. 2001. Malaysian Law: An introduction to the concept of law in Malaysia. 
Selangor: Pelanduk Publication(M) Sdn Bhd.

Salim Ali Farrar. 2008. The criminal Process in Malaysia: cases and material. Selangor: Peason Malaysia Sdn.Bhd.

Wu Min Aun. 1990. The Malaysian Legal System.Selangor Darul Ehsan: Longman Malaysia Sdn.Bnd. 